\title{
Integrative Review Literature on Objective Structured Clinical Examination and its implications in Nursing Education.
}

\author{
${ }^{1}$ Jansiraninatarajan, $\operatorname{Msc}(\mathrm{N}),{ }^{2}$ Deepa Shaji Thomas, $\operatorname{Msc}(\mathrm{N})$, \\ ${ }^{1,2}$ Lecturer, Fundamentals of Nursing and administration College of nursing, Sultan Qaboos University, \\ P.O.Box.No.66, Al-Khoud, Muscat, Sultanate of Oman.
}

\begin{abstract}
:
Background: One way to assess clinical competence of nursing students is the objective structured clinical examination (OSCE).

Purposes: This article explores the use of the Objective Structured Clinical Examination (OSCE) in undergraduate nursing education. The paper briefly reviews the utility of the OSCE as a strategy of measuring the clinical competence in nursing. It then offers a more 'in depth' reflection of the research literature pertaining to the students' perception on OSCE process, which acts as a basis when OSCE is used to assess nursing students.

Methodology: A review of the nursing literature was conducted through an initial search of the computerized databases of CINAHL, Pub Med, Google Scholar and Medline with full text. The initial search identified 351 papers. The selected search criteria included English language articles written between 2005 and 2013. Sixteen studies (13 quantitative and 3 qualitative) were included for the review.

Findings: The major findings reveal that OSCE is an effective tool for evaluation from faculty and student perspectives in all the studies. The key issues recognized include the complexity of the exam, time consumption, accelerated stress perception of the students and high cost in the conduction of the exam.

Conclusion: Therefore there is high possibility for further research in this area, as well as the need for careful guidance regarding the standardization of future OSCE as well as the use of OSCE in all the specialties of nursing. We conclude that OSCEs can be used most effectively in nurse undergraduate curricula to assess safe practice in terms of performance of psychomotor skills, as well as the knowledge associated with their application.
\end{abstract}

Key words: OSCE, Student and faculty perceptions, nursing education.

\section{Introduction:}

Nursing is a practice based profession underpinned by theoretical knowledge, both elements gained through a program of nursing education. It is acknowledged that clinical competency in Nursing encompasses clinical judgment. Nursing students must be able to draw on significant information and respond appropriately in a concerned and involved manner in patient care situations (Cox, 2000; Watson, Stimpson, Topping \& Porock, 2002). A major challenge for educators is how to evaluate the student's ability to select the necessary elements from his or her own knowledge and skill acquisition and transfer these skills into a wide range of clinical situations (National Council of State Boards of Nursing, 2009). Each student will have different exposure to different patients, making it difficult to measure individual and program outcomes (Rentschler, Eaton, Cappiello, McNally, \& McWilliam, 2007).

Nursing interest in OSCEs seemed to gain momentum after the relatively recent migration of nursing education from hospital based schools of nursing into institutions of higher education. This was followed by a perception that clinical skills had somehow become less important, an emphasis being placed instead upon theoretical knowledge (Sims, 2004). In response to this move into institutions of higher education and the perceived de-emphasis on clinical skills, the literature signals that educational providers now find themselves increasingly occupied with simulating the world where training would have occurred. These strategies for developing clinical competence have been further augmented by the use of OSCEs (Bradshaw \& Merriman, 2008) which seems to be the principal assessment method used (Joy \& Nickless, 2007). The complexity of the knowledge needed to ensure safe and effective nursing practice requires the development of multiple assessment approaches (Wellard et al., 2007).

One way to assess clinical competence of nursing students is the objective structured clinical examination (OSCE). The OSCE was first described by Harden et al. (1975) as a means to assess the clinical skills of final year medical students. So, ten years later, the OSCE, according to Ross et al, was for the first time adapted and implemented in the education of nurses at Mac Master University in 1984. 
The OSCE is defined as "an approach to the assessment of clinical competence in which the components of competence are assessed in a well planned or structured way with attention being paid to objectivity" (Harden 1988, p. 19), or as an assessment of well-defined clinical skills (Ward \& Willis 2006). According to Franklin (2005), the OSCE requires the student to actively demonstrate how she/he would apply acquired knowledge to a simulated 'real world' situation. It typically consists of a circuit or series of short assessment tasks (stations), each of which is assessed by an examiner using a predetermined, objective marking scheme (Bartfay et al 2004; Major 2005; Ward \& Barratt 2005). Traditional OSCE consists of a number of test stations (10 to 20 ), with the limited time duration of 5 to 10 minutes at which the respondents i.e. students are required to demonstrate competence in the given task, at every station.

OSCE has been positively appraised for allowing students to develop practice and improve clinical skills within a controlled environment (Bronan et al., 2006). The OSCE has become a well-established method of assessment in medical education (Ward \& Barratt, 2005) and is increasingly being used as a method of assessment in nursing and allied health curricula ( Nulty, D.D., Mitchell, M.L., Jeffrey,C.A., Henderson,A., Groves, M, 2011). Given that a large number of papers and researches of OSCE implementation were originally used in education of physicians, the objective of this study was to examine the feasibility assessment of clinical competence of nursing students using the objective structured clinical examination (OSCE).

\section{Aim}

The aim of the review was to describe the utility of the OSCE as a strategy of measuring Clinical competence in nursing. And also to explore the perceptions of students and faculty in using OSCE in nursing education.

\section{Search methods}

A review of the nursing literature was conducted through an initial search of the computerized databases of CINAHL, Pub Med, Google Scholar and Medline with full text. The initial search identified 351 papers. The selected search criteria included English language articles written between 2005 and 2013 using the keywords, nursing, OSCE, objective structured clinical evaluation and OSCE \& Nursing education.

\section{Inclusion criteria:}

- Original research studies

- $\quad$ primary data with full text

- Studies including OSCE in nursing students

- $\quad$ Published in English between 2005 and 2013

\section{Exclusion criteria:}

- Unpublished manuscripts or doctoral dissertations

- Review or opinion articles about OSCE

\section{Analysis of the findings:}

Two authors reviewed the papers and independently selected the articles eligible for the review. If multiple published reports from a same study were available, we included only one with the most detailed information, or published more recently. Data were extracted by two investigators and discrepancies were resolved by discussion.

\section{Search outcome}

Sixteen studies (13 quantitative and 3 qualitative) from 2005 to 2013, describing the use of some form of OSCE design in nursing education met the last inclusion criteria. A total of 351 articles were identified by electronic searches , 210 articles were excluded based on relevance and 141 articles were included based on abstracts and titles and 106 articles were excluded for citation duplication, of which 35 were full text articles focusing on OSCE. We finally excluded 19 articles, which included 5reviews, 4 unpublished manuscripts, 7 doctoral dissertations\& 3 opinion articles.. With detailed inspection and evaluation of the articles, 16 articles met the inclusion criteria. The analysis included various applications of this assessment, cost effectiveness of OSCE, students' and lectures' perceptions of the process and outcomes of OSCE. Methodological pathway is depicted in Fig-1.

\section{Results:}

A total of 16 studies conducted in 8 countries namely USA-2, Ireland-5, Iran-2, Egypt-3, Italy -1, Malaysia-1, and Saudi arabia-1, which met the inclusion criteria for this review. The articles were published between the years 2005-2013. Details of all 13 quantitative and 3 qualitative studies are shown in Table.1. 
Majority of the studies have used Researcher developed questionnaire to assess the effectiveness of OSCE. The major findings reveal that OSCE is an effective tool for evaluation from faculty and student perspectives in all the studies. But it was also perceived to be very stressful by the students. One study even noted that it is very costly to run an effective OSCE.

Majority of the students provided positive feedback about the OSCE attributes and agreed that the OSCE was a realistic assessment for the course about what they have learned and it could assess a wide range of learned materials (Eswi et al., 2013; Nemer \& Kandeel, 2009; Ghadah 2011). They also felt that the questions asked were of appropriate level, the time for each question was adequate (Eswi et al., 2013). Most students viewed OSCE as a fair assessment tool which allowed them to compensate in some areas and minimized their chances of failing (Nemer \& Kandeel, 2009; Selim et al, 2012). And also it is an objective method for determining their competence in the clinical setting (Beckham, 2013; Ghadah, 2011; Selim et al, 2012; Nemer \& Kandeel, 2009). Moreover the undergraduate nursing students felt that OSCE was an useful practical experience for them (Nemer \& Kandeel 2009; Selim et al, 2012).

Furthermore, few studies revealed that, OSCE scores provided true measures of essential clinical skills and were standardized(Nemer \& Kandeel, 2009), high correlation of the OSCE stations with the Intended Learning Outcomes (ILOs) and the clinical curriculum(Ghadah, 2011).

OSCE performance for nurses who were enrolled in a distance learning programme suggests that the need for nursing administrators to always test nurses' clinical skills performance, regardless of their years of experience, in order to ensure that the nurses can deliver safe and high quality care (Ahmed et al., 2009).

The psychiatric nursing students reported positive feedback about the quality of OSCE performance in terms of the clarity of the instructions of the exam, the sequence of OSCE stations, the reflection of the tasks taught and covering a wide range of clinical skills, highlighting the areas of weakness and the fairness of the exam(Selim et al, 2012)..

Most of the Midwifery students' were neutral/unsure of the OSCE as a strategy for assessing clinical competence and agreed that the examiner made them feel at ease (Muldoon et al,(2013).

The nursing students' perception about the disadvantages of OSCE include that the exams are complex and time consuming, professors are not completely objective, expensive, much personnel needed for careful organization(Ghadah, 2011).

In a retrospective study analyzing cost of OSCE, the high-end cost of the OSCE was $€ 11,319$, equaling $€ 145.23$ per student. The low-end cost was $€ 2521$, equaling $€ 31.51$ per student. Considering the highend cost, the most expensive phase was OSCE development followed by OSCE administration phase . The examination production phase and post-examination analysis and reporting accounted the least costs.

\section{Discussion:}

The distinguishing features of skill-based learning situations are that they are inherently variable, unpredictable, sometimes brief, high risk learning events which are not replicable, and this presents challenges for the quality assurance requirements of the assessment process (Cooper, Orrell \& Bowden; 2003, Hodges, 2011; Yorke,2011). The OSCE has become a well-established method of assessment in medical education (Ward \& Barratt 2005) and is increasingly being used as a method of assessment in nursing (Lauder et al., 2008; Jones et al., 2010) and allied health curricula (Bartfay et al 2004; Wessel et al 2003).

From our review it was evident that, OSCE is an effective method of evaluating the undergraduate nursing students. Nurse researchers argue that it is essential that objective evaluation of nursing students' clinical competence be incorporated in education, given that safety, quality, high standard and cost-effective care leading to positive client outcomes are the driving forces in the delivery of health care. A major challenge for educators is how to evaluate the student's ability to select the necessary elements from his or her own knowledge and skill acquisition and transfer these skills into a wide range of clinical situations (National Council of State Boards of Nursing, 2009). Each student will have different exposure to different patients, making it difficult to measure individual and program outcomes (Rentschler, Eaton, Cappiello, McNally, \& McWilliam, 2007).

We also found OSCE to fair, and objective in nature from all the reviewed studies. It is also emphasized in the article by Rushforth, 2007, that "In an OSCE, all students are assessed using exactly the same stations with the same marking scheme to make the assessment of clinical skills more objective rather than subjective". However, assessing students during a practicum can be highly variable in terms of the opportunities for assessment and the skills of the examiners. This means some students face more stringent examinations than other students which raises questions of the equity of in-situ exams. These observations would indeed support the suggestion that a multi-method approach to assess the different domains of competence is indicated.

Many authors agreed that OSCE is a valid, reliable and objective method of assessing clinical competence in various setting (Kurz, 2009; Mitchell et al.,2009; Walsh et al.,2009; Smith et al.,2012; Barry et al.,2013). To date, although extensive work has been done related to the psychometric properties of the OSCEs 
with undergraduate medical students and physician specialty education, limited evaluation has been undertaken in the context of nursing education. Further, because of the limitations of the nursing research thus far, it is imperative that nurse researchers devote time to examining the appropriateness of OSCEs as a form of clinical competence evaluation, including the testing of psychometric properties, that is, validity and reliability.

To overcome these and ensure acceptable reliability and content validity, a recurring recommendation in the literature is to include a larger number of short stations (approximately five minutes) (Schuwirth \& van der Vleuten 2003; Selby et al 1995; Bartfay et al., 2004). In particular, the need for more rigorous evaluation of OSCEs in nurse education programs has been highlighted (Khattab \& Rawlings 2001; Brosnan et al., 2006), as these assessments are directed towards assurances that passing students can practice safely in the clinical setting with patients. Constructing checklist items improves reliability to reported correlation coefficients of 0.8 to 0.9 (Doig CJ, Harasym PH, Fick GH, Baumber JS.2000).

Finally, it is important to examine that the benefits of this evaluation process are justifiable in the light of the costs of establishing and conducting an OSCE program. There is a scarcity of research in evaluating the cost of OSCE in nursing education except for one study which deems OSCE to be very costly. Setting up an OSCE program can be expensive, labor intensive, and administratively cumbersome (Newble 2004). Considering the economic crisis and the cost-containment measures applied in nursing education in the recent years, it is the need of the hour to work out strategies to make it as a cost effective one. Fortunately, these challenges can be overcome by thoughtful teamwork.

\section{Implications for practice}

Recommendations for future OSCE assessments include the following:

- Introduce a student self-assessment form to be completed after leaving the station. This could help students reflect on their performance and prompt identification of both their strengths and weaknesses

- Devise a marking system that has clarity.

- Research is needed on the psychometric properties of the objective structured clinical evaluation tools presently in use in nursing education and on the correlation between this and other evaluative methods currently used to evaluate nursing clinical competence.

- Research can be focused in the areas of effectiveness of OSCE as an evaluation tool in all specialties of nursing education.

- Cost effective strategies to run OSCE should be ventured.

- Video OSCE s can be introduced to reduce the stress and anxiety level of students.

\section{Conclusion:}

During undergraduate skill training in nursing, the OSCE provides both formative and summative assessment of cognitive and non-cognitive skills domains. Formative assessment identifies deficiencies and motivates remediation. Summative assessment pinpoints outstanding or suboptimal ability in particular areas. Globally, the OSCE provides immediate feedback to detect weaknesses within a curriculum, teaching methods, or both. Therefore, it is useful both for assessment and for the enhancement of educational effectiveness. Combining different testing modalities may give the best assessment of competence for various domains of knowledge, skills, and behavior. Despite the costs and logistical challenges to the implementation and maintenance of an OSCE program, compelling evidence exists for supporting and strengthening the modern OSCE as an integral part of undergraduate nursing courses.

Funding: profit sectors.

This research received no specific grant from any funding agency in the public, commercial or not-for-

\section{Conflict of interest:}

No conflict of interest has been declared by the authors.

\section{References}

[1]. Alinier, G. (2003). Nursing students' and lecturers' perspectives of objective structured clinical examination incorporating simulation. Nurse Education Today, 23(6), 419-426.

[2]. Barry, M., Noonan, M., Bradshaw, C., \& Murphy-Tighe, S. (2012). An exploration of student midwives' experiences of the Objective Structured Clinical Examination assessment process. Nurse Education Today, 32(6), 690-694.

[3]. Bartfay, W. J., Rombough, R., Howse, E., \& Leblanc, R. (2004). Evaluation. The OSCE approach in nursing education. The Canadian Nurse, 100(3), 18-23.

[4]. Bloomfield, J., Fordham-Clarke, C., Pegram, A., \& Cunningham, B. (2010). The development and evaluation of a computer-based resource to assist pre-registration nursing students with their preparation for objective structured clinical examinations (OSCEs). Nurse Education Today, 30(2), 113-117. 
[5]. Brosnan, M., Evans, W., Brosnan, E., \& Brown, G. (2006). Implementing objective structured clinical skills evaluation (OSCE) in nurse registration programmes in a centre in Ireland: a utilisation focused evaluation. Nurse Education Today, 26(2), $115-122$.

[6]. Byrne, E., \& Smyth, S. (2008). Lecturers' experiences and perspectives of using an objective structured clinical examination. Revista Espanola de Cirugia Ortopedica y Traumatologia, 52(4), 283-289.

[7]. Chen, A. C.-Y., Lee, M. S., Chen, W.-J., \& Lee, S.-T. (2013). Assessment in Orthopedic Training-An Analysis of Rating Consistency by Using an Objective Structured Examination Video. Journal of Surgical Education, 70(2), $189-192$.

[8]. Chipman, J. G., Webb, T. P., Shabahang, M., Heller, S. F., vanCamp, J. M., Waer, A. L., . . . Schmitz, C. C. (2011). A multiinstitutional study of the Family Conference Objective Structured Clinical Exam: a reliable assessment of professional communication. The American Journal of Surgery, 201(4), 492-497.

[9]. Chu, S.-Y., Lan, Y.-L., Kao, S.-P., Chen, T.-Y., \& Hsieh, M.-C. (2012). Effectiveness of rater consensus training in objective structured clinical examination using Kolb's experiential learning. Tzu Chi Medical Journal, 24(3), 155-156.

[10]. 18. Doig CJ, Harasym PH, Fick GH, Baumber JS. The effects of examiner background, station organization, and time of exam on OSCE scores assessing undergraduate medical students' physical examination skills. Acad Med 2000; 75(Suppl 10):S96-8.

[11]. Furlong, E., Fox, P., Lavin, M., \& Collins, R. (2005). Oncology nursing students' views of a modified OSCE. European Journal of Oncology Nursing, 9(4), 351-359.

[12]. Kurz, J. M., Mahoney, K., Martin-Plank, L., \& Lidicker, J. (2009). Objective Structured Clinical Examination and Advanced Practice Nursing Students. Journal of Professional Nursing, 25(3), 186-191.

[13]. Mitchell, M. L., Henderson, A., Groves, M., Dalton, M., \& Nulty, D. (2009). The objective structured clinical examination (OSCE): optimising its value in the undergraduate nursing curriculum. Nurse Education Today, 29(4), 398-404. doi: 10.1016/j.nedt.2008.10.007

[14]. Muldoon, K., Biesty, L., \& Smith, V. (2013). 'I found the OSCE very stressful': Student midwives' attitudes towards an objective structured clinical examination (OSCE). Nurse Education Today.

[15]. Palese, A., Bulfone, G., Venturato, E., Urli, N., Bulfone, T., Zanini, A., . . Dante, A. (2012). The cost of the objective structured clinical examination on an Italian nursing bachelor's degree course. Nurse Education Today, 32(4), 422-426.

[16]. Rushforth, H. E. (2007). Objective structured clinical examination (OSCE): Review of literature and implications for nursing education. Nurse Education Today, 27(5), 481-490.

[17]. Selim, A. A., Ramadan, F. H., El-Gueneidy, M. M., \& Gaafer, M. M. (2012). Using Objective Structured Clinical Examination (OSCE) in undergraduate psychiatric nursing education: Is it reliable and valid? Nurse Education Today, 32(3), $283-288$.

Figure:1. Flow chart showing methodological pathway

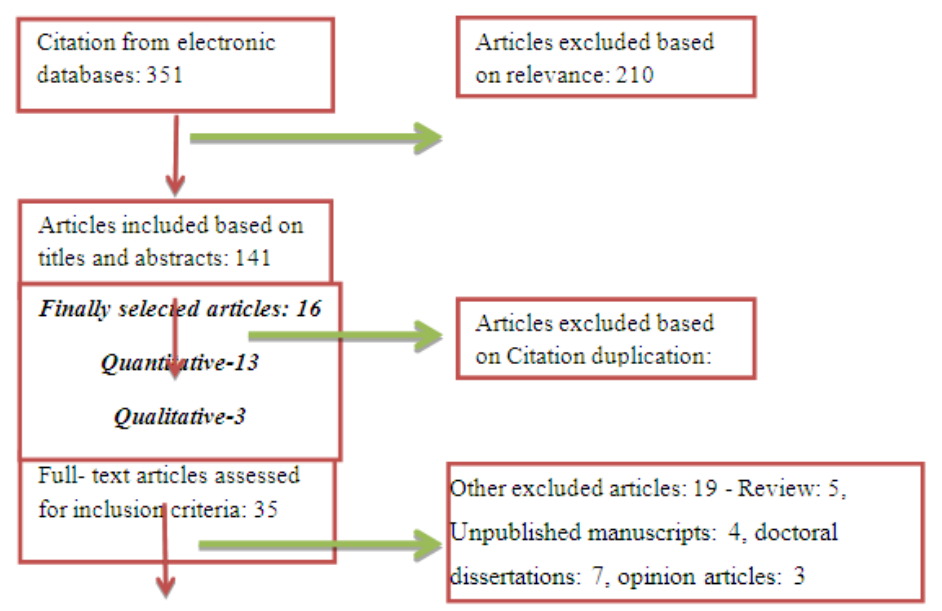

Table-1: Summary of the reviewed articles (Quantitative).

\begin{tabular}{|c|c|c|c|c|c|c|c|}
\hline \multirow{2}{*}{$\begin{array}{l}\text { Sl. } \\
\text { No }\end{array}$} & \multirow[t]{2}{*}{ Author \& Year } & \multicolumn{4}{|c|}{ Methodology } & \multirow[t]{2}{*}{ Study Purpose } & \multirow[t]{2}{*}{ Major findings } \\
\hline & & Participants & Design & Setting & Tools & & \\
\hline 1. & Eswi et al., (2013) & $\begin{array}{l}80 \text { nursing } \\
\text { students }\end{array}$ & $\begin{array}{l}\text { Descriptiv } \\
\text { e } \\
\text { Explorato } \\
\text { ry } \\
\text { Research }\end{array}$ & $\begin{array}{l}\text { Institute of } \\
\text { Nursing in } \\
\text { Riyadh city, } \\
\text { Saudi Arabia }\end{array}$ & $\begin{array}{l}\text { Pierre } \\
\text { OSCE } \\
\text { evaluation } \\
\text { questionnair } \\
\text { e }\end{array}$ & $\begin{array}{l}\text { To assess the } \\
\text { nursing } \\
\text { student's } \\
\text { perception and } \\
\text { feedback about } \\
\text { OSCE } \\
\text { examination }\end{array}$ & $\begin{array}{l}\text { Provided positive } \\
\text { feedback about } \\
\text { the OSCE } \\
\text { attributes that it } \\
\text { was a realistic } \\
\text { assessment for } \\
\text { the nursing } \\
\text { practical course. }\end{array}$ \\
\hline 2. & $\begin{array}{l}\text { Muldoon et al., } \\
\text { ( 2013) }\end{array}$ & $\begin{array}{l}33 \text {, third year } \\
\text { midwifery } \\
\text { nursing } \\
\text { students }\end{array}$ & $\begin{array}{l}\text { Descriptiv } \\
\text { e survey } \\
\text { design }\end{array}$ & $\begin{array}{l}\text { School of } \\
\text { nursing and } \\
\text { midwifery, } \\
\text { university of } \\
\text { Dublin trinity } \\
\text { college, } \\
\text { Ireland }\end{array}$ & $\begin{array}{l}\text { An 18-item } \\
\text { likert (1 to } 5 \\
\text { point) scale } \\
\text { developed } \\
\text { by the } \\
\text { researchers. }\end{array}$ & $\begin{array}{l}\text { To report } \\
\text { midwifery } \\
\text { students' } \\
\text { attitudes } \\
\text { towards a } \\
\text { lactation and } \\
\text { infant feeding } \\
\text { OSCE. }\end{array}$ & $\begin{array}{l}\text { The findings of } \\
\text { this study } \\
\text { identified that } \\
\text { midwifery } \\
\text { students were } \\
\text { neutral/unsure of } \\
\text { the OSCE as a } \\
\text { Strategy for }\end{array}$ \\
\hline
\end{tabular}


Integrative Review Literature on Objective Structured Clinical Examination and its implications ...

\begin{tabular}{|c|c|c|c|c|c|c|c|}
\hline & & & & & & & $\begin{array}{l}\text { assessing clinical } \\
\text { competence. }\end{array}$ \\
\hline 3. & $\begin{array}{l}\text { Martensson \& } \\
\text { Lofmark (2013) }\end{array}$ & $\begin{array}{l}203 \text { nursing } \\
\text { degree } \\
\text { students }\end{array}$ & $\begin{array}{l}\text { Descriptiv } \\
\text { e Study }\end{array}$ & $\begin{array}{l}\text { University in } \\
\text { central } \\
\text { Sweden }\end{array}$ & $\begin{array}{l}\text { Study } \\
\text { specific } \\
\text { questionnair } \\
\text { e adapted } \\
\text { from } \\
\text { Brosnan et } \\
\text { al (2006) }\end{array}$ & $\begin{array}{l}\text { To describe the } \\
\text { process of } \\
\text { developing } \\
\text { valid clinical } \\
\text { examinations } \\
\text { for nursing } \\
\text { students at the } \\
\text { end of } \\
\text { the final } \\
\text { semester }\end{array}$ & $\begin{array}{l}\text { A majority of } \\
\text { students found } \\
\text { the OSCE to be a } \\
\text { stressful, but } \\
\text { meaningful } \\
\text { and fair } \\
\text { examination and } \\
\text { more } \\
\text { meaningful. }\end{array}$ \\
\hline 4. & Beckham (2013) & $\begin{array}{l}52 \text { Gonzaga } \\
\text { University } \\
\text { family nurse } \\
\text { practitioner } \\
\text { students }\end{array}$ & $\begin{array}{l}\text { Retrospec } \\
\text { tive, } \\
\text { longitudin } \\
\text { al study. }\end{array}$ & USA & $\begin{array}{l}\text { Standardize } \\
\text { d scoring } \\
\text { sheet. }\end{array}$ & $\begin{array}{l}\text { This study } \\
\text { examined the } \\
\text { correlation of } \\
\text { the performance } \\
\text { of FNP students } \\
\text { on OSCEs with } \\
\text { other clinical } \\
\text { evaluative } \\
\text { Methods. }\end{array}$ & $\begin{array}{l}\text { This study } \\
\text { demonstrates a } \\
\text { moderate } \\
\text { correlation } \\
\text { between } \\
\text { clinical } \\
\text { evaluation and } \\
\text { OSCEs in the } \\
\text { first clinical } \\
\text { course, } \\
\text { suggesting that } \\
\text { OSCEs in FNP } \\
\text { programs can be } \\
\text { useful in } \\
\text { clinical courses. }\end{array}$ \\
\hline 5. & Selim et al (2012) & $\begin{array}{l}76 \text { B.Sc } \\
\text { Nursing } \\
\text { Students }\end{array}$ & $\begin{array}{l}\text { Descriptiv } \\
\text { e Study }\end{array}$ & $\begin{array}{l}\text { Psychiatric } \\
\text { Nursing and } \\
\text { Mental } \\
\text { Health } \\
\text { Department, } \\
\text { Alexandria } \\
\text { University, } \\
\text { Egypt. }\end{array}$ & $\begin{array}{l}\text { The } \\
\text { researcher } \\
\text { made } \\
\text { Questionnai } \\
\text { re }\end{array}$ & $\begin{array}{l}\text { The main aim } \\
\text { was to test the } \\
\text { application, } \\
\text { validity and } \\
\text { reliability of the } \\
\text { OSCE in } \\
\text { undergraduate } \\
\text { psychiatric } \\
\text { nursing } \\
\text { education }\end{array}$ & $\begin{array}{l}\text { The psychiatric } \\
\text { nursing OSCE } \\
\text { proved to be a } \\
\text { reliable and valid } \\
\text { method in } \\
\text { assessing } \\
\text { psychiatric } \\
\text { nursing clinical } \\
\text { competencies. }\end{array}$ \\
\hline 6. & $\begin{array}{l}\text { Bagheri et al., } \\
\text { Iran ( 2012) }\end{array}$ & $\begin{array}{l}25 \text { students of } \\
\text { the second } \\
\text { term of } \\
\text { fundamentals } \\
\text { of nursing. }\end{array}$ & $\begin{array}{l}\text { Comparati } \\
\text { ve } \\
\text { Descriptiv } \\
\text { e Study }\end{array}$ & $\begin{array}{l}\text { Nursing and } \\
\text { Midwifery } \\
\text { School of } \\
\text { Mashhad, } \\
\text { Iran. }\end{array}$ & $\begin{array}{l}\text { The } \\
\text { researcher } \\
\text { made } \\
\text { Questionnai } \\
\text { re. }\end{array}$ & $\begin{array}{l}\text { Comparing } \\
\text { Stressors in } \\
\text { basic clinical } \\
\text { skills } \\
\text { evaluation with } \\
\text { traditional and } \\
\text { OSCE methods } \\
\text { in nursing } \\
\text { students }\end{array}$ & $\begin{array}{l}\text { OSCE is a more } \\
\text { accurate, fairer, } \\
\text { and more } \\
\text { effective method } \\
\text { in creating } \\
\text { learning } \\
\text { motivation for } \\
\text { students but it is } \\
\text { more complex } \\
\text { and stressful than } \\
\text { the } \\
\text { Traditional } \\
\text { method. }\end{array}$ \\
\hline 7. & $\begin{array}{l}\text { Palese et al., } \\
(2012)\end{array}$ & $\begin{array}{l}80 \text { second } \\
\text { year nursing } \\
\text { students }\end{array}$ & $\begin{array}{l}\text { Retrospec } \\
\text { tive study }\end{array}$ & $\begin{array}{l}\text { Udine } \\
\text { University, } \\
\text { Italy }\end{array}$ & $\begin{array}{l}\text { Cost } \\
\text { variables } \\
\text { identified } \\
\text { by Reznick } \\
\text { et al } \\
\text { guidelines(1 } \\
\text { 993) }\end{array}$ & $\begin{array}{l}\text { To analyze the } \\
\text { cost of OSCE } \\
\text { retrospectively. }\end{array}$ & $\begin{array}{l}\text { The high end } \\
\text { cost adopting the } \\
\text { OSCE amounted } \\
\text { to } € 145.23 \text { per } \\
\text { student, while } \\
\text { low end cost } \\
\text { were } € 31.51 \text { per } \\
\text { student which } \\
\text { was considered } \\
\text { to be costly. }\end{array}$ \\
\hline 8. & Ghadah (2011) & $\begin{array}{l}100 \text { nursing } \\
\text { students }\end{array}$ & $\begin{array}{l}\text { Descriptiv } \\
\text { e Study }\end{array}$ & $\begin{array}{l}\text { Assuit } \\
\text { University, } \\
\text { Egypt }\end{array}$ & $\begin{array}{l}\text { A self- } \\
\text { administere } \\
\mathrm{d} \text { structured } \\
\text { questionnair } \\
\mathrm{e}\end{array}$ & $\begin{array}{l}\text { Study to assess } \\
\text { the third year } \\
\text { nursing } \\
\text { student's } \\
\text { perception } \\
\text { about an OSCE }\end{array}$ & $\begin{array}{l}\text { The majority of } \\
\text { the students } \\
\text { considered the } \\
\text { quality of } \\
\text { examination was } \\
\text { excellent and } \\
\text { that there is more } \\
\text { need for careful } \\
\text { preparation and } \\
\text { organization of } \\
\text { OSCE. }\end{array}$ \\
\hline
\end{tabular}


Integrative Review Literature on Objective Structured Clinical Examination and its implications ...

\begin{tabular}{|c|c|c|c|c|c|c|c|}
\hline 9. & $\begin{array}{l}\text { Hosseini et al., } \\
\text { (2011) }\end{array}$ & $\begin{array}{l}49 \text { nursing } \\
\text { students }\end{array}$ & $\begin{array}{l}\text { Descriptiv } \\
\text { e Study }\end{array}$ & $\begin{array}{l}\text { Isfahan } \\
\text { University of } \\
\text { Medical } \\
\text { Sciences, Iran }\end{array}$ & $\begin{array}{l}\text { A self- } \\
\text { administere } \\
\text { d structured } \\
\text { questionnair } \\
\text { e }\end{array}$ & $\begin{array}{l}\text { To evaluate } \\
\text { nursing } \\
\text { students' view } \\
\text { towards OSCE } \\
\text { test. }\end{array}$ & $\begin{array}{l}\text { OSCE test has } \\
\text { been good in } \\
\text { terms of } \\
\text { equipment and } \\
\text { facilities, } \\
\text { conditions of } \\
\text { holding the } \\
\text { examination and } \\
\text { in terms of } \\
\text { physical } \\
\text { environment, } \\
\text { students' view } \\
\text { was moderate. }\end{array}$ \\
\hline 10. & $\begin{array}{l}\text { Nemer \& } \\
\text { Kandeel (2009) }\end{array}$ & $\begin{array}{l}724 \text { under } \\
\text { graduate } \\
\text { nursing } \\
\text { students }\end{array}$ & $\begin{array}{l}\text { Cross } \\
\text { Sectional } \\
\text { Descriptiv } \\
\text { e Study }\end{array}$ & $\begin{array}{l}\text { Mansoura } \\
\text { University, } \\
\text { Egypt. }\end{array}$ & $\begin{array}{l}\text { Pierre et al., } \\
(2004) \\
\text { OSCE } \\
\text { evaluation } \\
\text { questionnair } \\
\text { e. }\end{array}$ & $\begin{array}{l}\text { To investigate } \\
\text { nursing } \\
\text { students ' } \\
\text { feedback about } \\
\text { the OSCE as an } \\
\text { assessment tool } \\
\text { for their clinical } \\
\text { skills. }\end{array}$ & $\begin{array}{l}\text { OSCE has been } \\
\text { accepted by the } \\
\text { majority of } \\
\text { nursing students } \\
\text { as an evaluation } \\
\text { tool for their } \\
\text { clinical skills. }\end{array}$ \\
\hline 11. & $\begin{array}{l}\text { Ahmed., et al., } \\
(2009)\end{array}$ & $\begin{array}{l}\text { 311 Distance } \\
\text { learning } \\
\text { nursing } \\
\text { students }\end{array}$ & $\begin{array}{l}\text { Cross } \\
\text { Sectional } \\
\text { Survey }\end{array}$ & $\begin{array}{l}\text { School of } \\
\text { Nursing } \\
\text { Open } \\
\text { University } \\
\text { Malaysia }\end{array}$ & $\begin{array}{l}\text { The } \\
\text { researcher } \\
\text { made } \\
\text { check list }\end{array}$ & $\begin{array}{l}\text { To assess } \\
\text { clinical } \\
\text { competence } \\
\text { level among } \\
\text { distance } \\
\text { learning } \\
\text { nursing } \\
\text { students', using } \\
\text { an objective } \\
\text { structured } \\
\text { clinical } \\
\text { examination } \\
\text { (OSCE). }\end{array}$ & $\begin{array}{l}\text { The findings } \\
\text { revealed that } \\
43(14 \%) \text { of the } \\
\text { nurses have level } \\
\text { four } \\
\text { competencies, } \\
\text { which indicates } \\
\text { that they could } \\
\text { perform the tasks } \\
\text { correctly and } \\
\text { complete. }\end{array}$ \\
\hline 13. & $\begin{array}{l}\text { Furlong et al } \\
(2005)\end{array}$ & $\begin{array}{l}185 \text { nursing } \\
\text { students }\end{array}$ & $\begin{array}{l}\text { Non } \\
\text { experimen } \\
\text { tal post } \\
\text { only } \\
\text { evaluation } \\
\text {. }\end{array}$ & $\begin{array}{l}\text { School of } \\
\text { nursing, } \\
\text { University } \\
\text { college } \\
\text { Dublin, } \\
\text { Ireland }\end{array}$ & $\begin{array}{l}\text { The } \\
\text { researcher } \\
\text { made } \\
\text { check list }\end{array}$ & $\begin{array}{l}\text { To assess the } \\
\text { students' } \\
\text { perceptions the } \\
\text { overall efficacy } \\
\text { and relevance } \\
\text { of the OSCE in } \\
\text { testing clinical } \\
\text { skills and their } \\
\text { views on stress } \\
\text { and anxiety } \\
\text { associated with } \\
\text { this form of } \\
\text { evaluation }\end{array}$ & $\begin{array}{l}\text { The results } \\
\text { indicate that } \\
\text { while students } \\
\text { acknowledge that } \\
\text { the OSCE was } \\
\text { stressful, they } \\
\text { appreciated the } \\
\text { efficacy and } \\
\text { relevance of this } \\
\text { assessment } \\
\text { method. }\end{array}$ \\
\hline
\end{tabular}

Table-2: Summary of the reviewed articles (Qualitative).

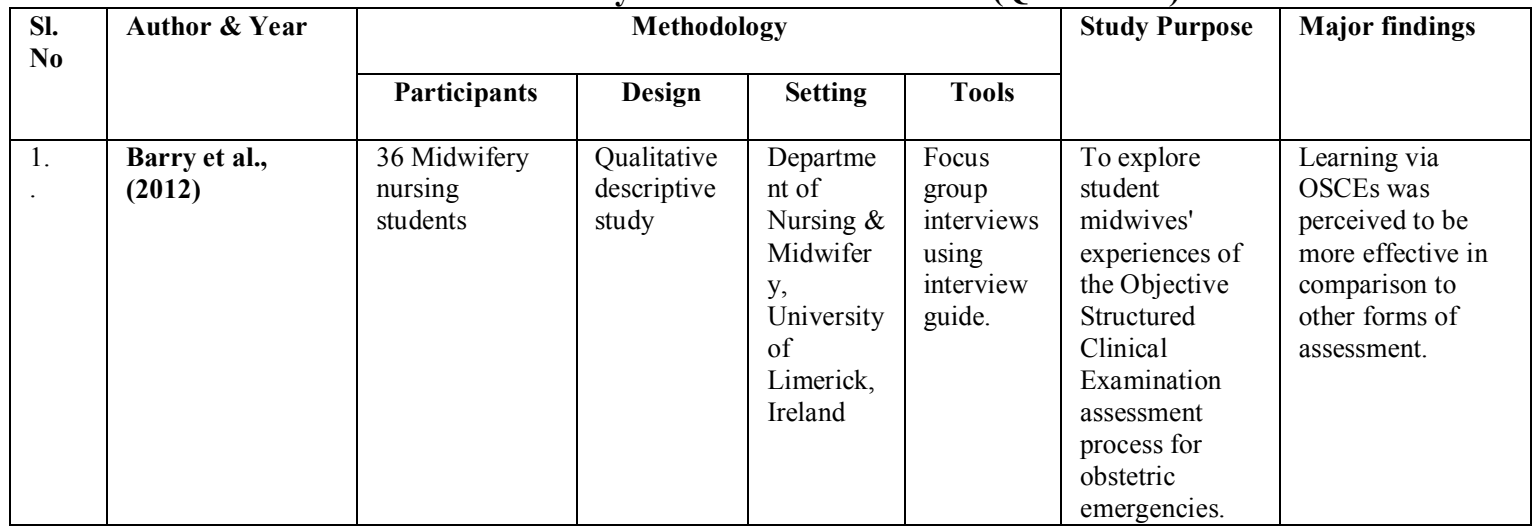


Integrative Review Literature on Objective Structured Clinical Examination and its implications ...

\begin{tabular}{|c|c|c|c|c|c|c|c|}
\hline 2. & $\begin{array}{c}\text { Byrne and } \\
\text { Smyth, (2007) }\end{array}$ & $\begin{array}{l}11 \text { Nurse } \\
\text { educators }\end{array}$ & $\begin{array}{l}\text { Exploratory } \\
\text { descriptive } \\
\text { study }\end{array}$ & $\begin{array}{l}\text { School of } \\
\text { Nursing } \\
\text { and } \\
\text { Midwifer } \\
\text { y, } \\
\text { National } \\
\text { University } \\
\text { of Ireland, } \\
\text { Galway, } \\
\text { Ireland }\end{array}$ & $\begin{array}{l}\text { Focus } \\
\text { group } \\
\text { interviews } \\
\text { using } \\
\text { Semi } \\
\text { structured } \\
\text { interview } \\
\text { schedule. }\end{array}$ & $\begin{array}{l}\text { To analyze } \\
\text { nurse } \\
\text { educators' } \\
\text { experiences and } \\
\text { perspectives of } \\
\text { assessing } \\
\text { students' } \\
\text { Clinical } \\
\text { competence } \\
\text { using an OSCE. }\end{array}$ & $\begin{array}{l}\text { Their experiences } \\
\text { and perspectives } \\
\text { were very positive } \\
\text { about using } \\
\text { OSCE. }\end{array}$ \\
\hline 3. & $\begin{array}{l}\text { Brosnan et al., } \\
(2006)\end{array}$ & $\begin{array}{l}20 \text { I and II year } \\
\text { nursing } \\
\text { students, } \\
8 \text { Nurse } \\
\text { educators. }\end{array}$ & $\begin{array}{l}\text { Utilization } \\
\text { focused } \\
\text { evaluation } \\
\text { approach. }\end{array}$ & $\begin{array}{l}\text { Departme } \\
\text { nt of } \\
\text { Nursing } \\
\text { and } \\
\text { Healthcar } \\
\text { e Studies, } \\
\text { Kerry, } \\
\text { Ireland }\end{array}$ & $\begin{array}{l}\text { Focus } \\
\text { group } \\
\text { interviews } \\
\text { using } \\
\text { open } \\
\text { ended } \\
\text { questions. }\end{array}$ & $\begin{array}{l}\text { To evaluate the } \\
\text { process and } \\
\text { outcomes of } \\
\text { OSCE from the } \\
\text { perspective of } \\
\text { the major } \\
\text { Stake holder } \\
\text { groups. }\end{array}$ & $\begin{array}{l}\text { The OSCE process } \\
\text { was found to have } \\
\text { a positive impact } \\
\text { on all } \\
\text { stakeholders. }\end{array}$ \\
\hline
\end{tabular}

